\title{
The Impact of Student Support Services on Students Enrolled for National Certificate Vocational in Motheo District, Free State, South Africa
}

\author{
Joseph Ramathibela Maimane
}

Central University of Technology, South Africa

Copyright $(2016$ by authors, all rights reserved. Authors agree that this article remains permanently open access under the terms of the Creative Commons Attribution License 4.0 International License

\begin{abstract}
The Department of Higher Education and Training introduced the national certificate vocational (NCV) in Further Education and Training colleges in January 2007. The entry requirement for this qualification is Grade 9. However, this qualification has attracted students with grades between Grades 9 and 12. Students enrolling for the NCV qualification have the different educational background and different needs. Appropriate student support system to accommodate these diverse students is imperative for them to enhance opportunities afforded by the college. Once students are conscious of what the college does for them, it will operate effectively and at its maximum. The focus of the study is to explore the impact of student support services have on students enrolled for national certificate vocational in Motheo District, Free State Province, South Africa and their contribution to the academic success of students. Data was collected from a random sample of 120 students ( 85 females and 35 males). A mixed-method approach was used to collect data. Students who signed the agreement form to participate in the study were requested to respond to thirteen questions relating to the student support services. The Microsoft Excel 2010 was used in the analysis of data. The results lead to the conclusion that student support services, if coordinated effectively, could contribute immensely to students' academic achievement and bigger opportunities.
\end{abstract}

Keywords National Certificate Vocational, Student Support Services, Enrollment, Program, Life-long Learning

\section{Introduction}

During the past years, there has been a significant growth of learner enrollment in the NCV programs that are being provided by the Department of Higher Education and Training (DHET) through the further education and training colleges in South Africa. These developments necessitated the establishment and publication of a student support services (SSS) framework, which was completed in April 2008 by the DHET. The SSS Framework provides guidelines to students in achieving academic success (Department of Education, 2008). All the colleges were instructed to implement the students support services framework. Motheo District TVET Colleges were obliged to establish the student support services unit. The most crucial challenges which the TVET College had to encounter were, the shift in student population: multiple language groups in one classroom, different age groups and therefore different students' needs, higher levels of cognitive demand in new programs and thus a wider range of academic support needs, and a shift in student population. The range of factors in higher education that had an impact on students 'retention included pre-entry information, preparation and admission processes, induction and transition support (Crosling, Heagney and Thomas 2009). The recent research done on student support services by (Gil-Jaurena, 2014) focused on student support services in open and distance education. It was in areas pertaining to the evaluation of student support services; support services for entry and first-year students; services for after completion of distance learning programs; use of technology for students' support services, etc. The shift placed the focus on the integration of support with teaching and learning, instead of isolating student support services as a separate structure within the institution.

\section{Problem Statement}

In essence, the problem that is to be investigated in this study focuses on the impact made by student support services on students' academic success at Motheo District TVET College. If one has to understand the root of the problem, the answer will have to be found to the following 
questions.

\subsection{Research Questions}

- To what degree does the student support services impact on the academic success of students enrolled in NCV programs at the TVET College in Motheo District, Free State, South Africa?

- Do student support services benefit students in performing to the best of their ability?

- What recommendations could be made from the results in the current provision of student support services at the TVET College?

\subsection{Aims and Objectives}

The aim of the study is to determine the impact student support services has on students enrolled for national certificate vocational in Motheo District, Free State, South Africa.

\subsubsection{Objectives}

- To determine to what extent the student supports service contribute to the academic success of students at the TVET College.

- To establish if student support services do motivate students to perform to the best of their ability.

- To formulate recommendations that may serve in the current provision of student support services at the college.

\section{Literature Review}

The starting point for all prospective college students is to make career choices that match their interests, abilities, and aptitude. In order for the college to be able to provide it must have a vision that would make it possible to respond to the needs of its clients. The aim of the college in Motheo District is:

The Student Support Unit strives to provide all the necessary support and development service to make the time a student spends at all Colleges as fulfilling as possible. The Students Support Services plays a major role within Motheo TVET College to ensure inclusive access to education and training, and to develop individuals holistically (Motheo TVET College Prospectus 2015: 26).

Students are supported at registration, during their studies, and at exit level. The following are some of the support services that are provided the college, student induction programmes, educational advising, library assistance, study skills, examination, language assistance, computer assistance, placement, occupational and subject choices, financial aid \& bursaries, entrepreneurial skills training, sport assistance, cultural activities, and social adjustment, to name a few.

The above-mentioned issues are indicative of the fact that it is important when students enroll for the right programs and courses in order to reach their goals. The selection and placement that the students make should be accurate in order for them to be adequately prepared in terms of knowledge, skills and motivation so that they can develop in their specific fields. Lack of informed career planning and decision-making may result in wasted money, frustration, discontent, and hardship. According to Steyn (2014), "support services are specialized functions that are not typically education system." Van Schalkwyk (in Dekker \& Van Schalkwyk (eds.) confirmed that support services are organized in a system to assist individual colleges so that their education can be more effective. Education support services as part and parcel of the entire school practice include all human and other resources that provide support to individual students other aspects of the education system.

While these services attempt to minimize and remove learning and development barriers, they also focus on the prevention of such barriers and on the development of a supporting learning environment for learners. Mahlo (2011) argues that since education support services are under-resourced and unable to deal with the large numbers of learners in need, their barriers to learning are not being addressed. Taking all of the above into consideration, Steyn, Steyn, De Waal and Wolhuter 2002) concluded that "education support services (are services) aimed at achieving effective teaching and learning". The latest available definition (Steyn and Wolhuter, 2008) is that support services can be defined as the specialized non-educational services needed to improve the quality and effectiveness of educational activities" does not differ substantially from the previous definitions cited above.

Through vocational guidance and counseling students need to know which occupations and jobs are best suited towards their interests, values, and skills, and they have to understand the kind of qualifications and personal attributes required. They may have an interest one particular job but they also have to know whether there is a demand for the occupations and jobs, and how changes in the labor market will affect their chosen occupational field. Mwamwenda, (2004) further states that counselors can only guide and counsel learners, but the final decisions are theirs. Career guidance helps students to find out which courses will complement their choices and what the entrance requirements for these courses are. They also need to know what costs will be involved to attain the specific qualification and what options are available to attain further qualifications on completion of their college studies.

An early understanding that the college offers various types of support programs, for example, career guidance and counseling, academic support, health and well-being, life orientation and financial aid, is crucial. It is of importance that students know who they are in terms of interests, personality, attributes, abilities and motivations. 
Only if such information is available can they explore and end up in careers in which they are interested and for which they have the required aptitude. Support services are according to Steyn and Wolhuter, (2008) one of the four basic components of any education system. Students' first experience of the college is that of being welcomed into an organized, student-focused environment where everything is done to help them become successful members of the college community. This leads to a sense of pride in and belonging to their new college and motivates them to become involved in their academic work when the academic timetable commences.

An early identification of academic support needs is crucial as part of the system because students will be able to determine where to find assistance. By the time, it comes to the mid-year or final examinations it is often too late to remedy the situation. While the assessment tools used during orientation are helpful in showing areas where students are capable and interested, they do not fully identify academic support needs. The study is thus significance in assisting all the stakeholders, lecturers, students and parents to understand the impact of student support services.

\section{Methodology}

A mixed method design was used in this study in order to obtain answers to the research questions. The mixed method is a combination of quantitative and qualitative methods used to collect and analyze the data. Creswell (2005) define mixed method as a procedure for collecting, analyzing and mixing of both quantitative and qualitative data at some stage of the research process within a single study to understand a research problem more completely. In this study the researcher wanted to investigate the impact of students' perceptions of student support services at a TVET College.

\subsection{Population and Sampling}

The target population of the study consisted of all those students who were in their second semester of study at a TVET College. Due to the fact that it was not possible to do research with the entire population a sample was randomly selected from the population of 456 students. To obtain a comprehensive view of the perceptions of the students on the issue of student support services, students with diverse cultural background and beliefs formed part of the sample. A random sample of 120 participants ( 85 females and 35 males) who were either in L2 or L3 of NCV program with the average age range of 22-24 participated in the study. The participant's names were not revealed because of ethical considerations as suggested by Creswell (2014). Informed consent and ethical consideration were attained in terms of confidentiality, voluntary participation, benefit and anonymity. The researcher referred to them as Student A, B,
C, and D.

\subsection{Research Instruments}

\subsubsection{Questionnaire}

The data source was the questionnaire developed by the researcher. The first, Section A contains information on the demographic profile of the students. The second, Section B was seven rating scale items pertaining to student support services at the college. Participants were asked to rate the items according to 5-point Likert-type scale, ranging from "strongly agree" to "strongly disagree." The items were organized into three subareas that are, (1) Policy and registration, (2) Code of conduct and selection, (3) Building layout. Section C: consisted three open-ended questions that asked participants for their (a) definition of student support services, (b) the benefit of having student support services as one of the programs and (c) strategies that could be used to improve the program.

The researcher requested that participants put exactly what they thought about student support services in a campus situation. A larger questionnaire with plenty of space for question and answers is more encouraging to the participants. No more than one question should be presented on a single line. That was strictly observed by the researcher. Actually, the researcher prepared his questionnaires according to the recommendation stated above.

The quantitative research method is used to test the theories about reality, and to look for cause and effect used to gather data to test the questions (Inankova, Creswell, and Clark, 2007:255).

\subsubsection{Interviews}

A semi-structured interview was conducted with four volunteers from participating students whose names were not revealed. The semi-structured interview questions were used to obtain in-depth information and to answer the second research question. Questions emanated from research questions of the study. They were used to measure the objectives of the study. The four participants responded to three questions the interviewer asked them. The interview was meant to last for 30-45 minutes. They focused on the following:

- The understanding of student support services.

- Academic opportunities of being a student at the college

- The suggestion of strategies of addressing problems related to student support services.

The questionnaire and interviews were tested with a group of NCV level 2 students in order to clarify some concepts. It was also given to two English lecturers for grammar and clarity. The intention of such an above exercise was to evaluate the questions and to check them for ambiguity, question structure, clarity of the questions, language suitability, and the scope to elicit honest responses 
Fraenkel and Wallen, (1990); Martins, Loubser \& Van Wyk (1996). This was affirmed by Christensen, and Johnson (2012); Conrad, and Serlin, (2011) that pilot testing is important in generating questions and strategies to questioning and can contribute to the credibility of the study. The measures taken were used for the purpose of enhancing trustworthiness of data (Clark, 2000). The multi-method strategy of using questionnaires, and in-depth interviews permitted triangulation of data and increase the credibility of the findings. Ethical issues were observed when administering the questionnaires and conducting the interview.

\subsection{Procedure}

On a Friday of the first week of registration, the research piloted the questionnaire to four (4) randomly selected students from automotive repair and maintenance classes. The intention of such an above exercise was to evaluate the questions and to check them for ambiguity, question structure, clarity of the questions, language suitability and the scope to elicit honest responses. Once the questionnaire was refined, it was then administered to the target group to respond to. It was expatiated to students that the responses they were to provide was not binding, but its intention was to find the general picture of student support services, so as to gather data and suggest a strategy that could improve student academic life at the college. A schedule was organized with the four students for an interview. The participants were also given assurance on confidentiality and respect of their personality.

\section{Data Analysis}

Data from questionnaires were compiled, sorted, edited, classified and coded into a coding spread-sheet and analyzed using a computerized data analysis package known as Microsoft Excel 2010.

\section{Section: A}

This section reports on the demographic particulars of the participants.

Table 1. Gender and Age

\begin{tabular}{|c|c|c|c|}
\hline \multicolumn{2}{|c|}{ Frequency Table } & & \\
\hline \multicolumn{2}{|c|}{ Gender } & $\mathrm{N}$ & $\%$ \\
\hline \multirow{2}{*}{} & Male & 35 & 29.2 \\
\cline { 2 - 4 } & Female & 85 & 70.8 \\
\cline { 2 - 4 } & Total & 120 & 100 \\
\hline \multirow{2}{*}{ Age } & $18-25$ & $\mathrm{~N}$ & $\%$ \\
\hline & $25-35$ & 45 & 54.2 \\
\cline { 2 - 4 } & $36-45$ & 10 & 37.5 \\
\cline { 2 - 4 } & Total & 120 & 8.3 \\
\hline
\end{tabular}

The above Table 1 reflects that 65 participants (54.2\%) are between the ages $18-25$ while $45(37.5 \%)$ are between the ages 25-35 years and $10(8.3 \%)$ are between $30-39 \%$. Basically, the majority of respondents are between 18-25 years old. Majority $85(70.8 \%)$ of participants are female in the study with 35 (29.2) being male.

\section{Section B}

In this section, data is presented and the results were in a table format as shown below.

\section{Presentation and Interpretation of Students' Perception for Accessing the College}

Table 2: Students' perception of accessing the college

Table 2.1. Policy and Registration

\begin{tabular}{|c|c|c|c|c|c|c|c|}
\hline $\begin{array}{c}\text { Core of } \\
\text { question }\end{array}$ & \multicolumn{3}{|c|}{ Frequency } & \multicolumn{3}{c|}{ Percentage } & SD \\
\hline & $1 / 2$ & 3 & $4 / 5$ & $1 / 2$ & 3 & $4 / 5$ & \\
\hline Q1. policy & 24 & 6 & 90 & 20 & 5 & 75 & 31,2 \\
\hline $\begin{array}{c}\text { Q2. } \\
\text { Registratio } \\
\text { n, bursary } \\
\text { forms }\end{array}$ & 72 & 6 & 42 & 59 & 6 & 35 & 24,3 \\
\hline
\end{tabular}

More than half of the students (55\%) for Q1 and Q2 indicate that admission and user-friendly registration forms are makes it possible to access the college.

The majority of students (69\%) perceive the above Q3/Q4/Q5 as being necessary for them to be able to access information regarding opportunity to teaching and learning at the college.

Table 2.1 represents admission policy and registration the following questions were asked to find the depth of the student's perception: "Q1 there is admission policy and Q2 registration forms are user friendly". More than half of the students $(55 \%)$ for Q1 (75\%) strongly agree that there is admission policy and Q2 (59\%) registration forms are not user-friendly which it makes it impossible to access the college.

Table 2.2. Code of conduct and information for selection

\begin{tabular}{|c|c|c|c|c|c|c|c|}
\hline $\begin{array}{c}\text { Core of } \\
\text { question }\end{array}$ & \multicolumn{3}{|c|}{ Frequency } & \multicolumn{3}{c|}{ Percentage } & SD \\
\hline & $1 / 2$ & 3 & $4 / 5$ & $1 / 2$ & 3 & $4 / 5$ & \\
\hline $\begin{array}{c}\text { Q3. Code } \\
\text { of conduct }\end{array}$ & 36 & 6 & 78 & 30 & 5 & 65 & 29,8 \\
\hline $\begin{array}{c}\text { Q4. } \\
\text { selection }\end{array}$ & 20 & 6 & 94 & 17 & 5 & 78 & 32,3 \\
\hline $\begin{array}{c}\text { Q5. } \\
\text { Program } \\
\text { with easy } \\
\text { steps }\end{array}$ & 34 & 10 & 77 & 28 & 8 & 64 & 32,7 \\
\hline
\end{tabular}

The majority of students $(69 \%)$ perceive the above Q3 $(65 \%) / \mathrm{Q} 4(78 \%) / \mathrm{Q} 565 \%)$ as being necessary for them to be able to access information regarding opportunities to teaching and learning at the college. This might be due to the fact that there is code of conduct, availability of information and simple and easy steps to follow. 
Table 2.3. Registration and building layout:

\begin{tabular}{|c|c|c|c|c|c|c|c|}
\hline $\begin{array}{c}\text { Core of } \\
\text { question }\end{array}$ & \multicolumn{3}{|c|}{ Frequency } & \multicolumn{3}{c|}{ Percentage } & SD \\
\hline Items & $1 / 2$ & 3 & $4 / 5$ & $1 / 2$ & 3 & $4 / 5$ & \\
\hline $\begin{array}{c}\text { Q6. } \\
\text { Placement }\end{array}$ & 21 & 5 & 94 & 18 & 4 & 78 & 34,2 \\
\hline $\begin{array}{c}\text { Q7. Building } \\
\text { layout }\end{array}$ & 24 & 6 & 90 & 20 & 5 & 75 & 34,0 \\
\hline
\end{tabular}

1=Strongly Disagree 2=Disagree $3=$ Not sure $4=$ Agree $5=$ Strongly Agree

The majority of the students $(77 \%)$ are of the opinion that information about the dates for registration and the building lay-out Q6 (78\%) /Q7 (75\%)) should be indicated in the prospectus booklet in-order to make it possible for students to reach administration offices in time.

\section{Findings of the Questionnaires}

The findings of this study, to a very great extent, at the Bloemfontein TVET College in particular, suggests that effective students support services as provided currently at the campus has impact on their level of information regarding their studies. The majority of participants indicated through their responses that there is a probability that student support services contribute to the academic success. $77 \%$ of students agreed that for SSS to contribute to their academic success teaching and learning environment should be conducive for them to access without hurdles. They also agreed $69 \%$ that student support services influence their academic success because of its programs. They further agreed (55\%) although just more than half of them, that the programs are helpful as they enable them to solicit information by having the opportunity using top of the range technology.

\section{Data Analysis: Students' Interviews}

Students' interviews were used in this research to supplement information obtained from the statistical results above. To capture the tone and allow greater authenticity, transcriptions were precise and included utterances such as "aah" and "yeah." The researcher verified the accuracy of each transcription.

Data generated by the semi-structured interview based on the three questions were asked by the interviewer:

Question 1: What is your understanding of Student Support Services?

When the participants were asked the above questions, eight themes emerged in their responses: student needs, guidance, community of students, anxiety, policy, resources, security, access of information and buildings.

Student A: "Mmm...I think a student support service has to do with how our needs as students are to be looked at by the management and the teaching staff. Wait! It has to do with the guidance which we are to get as students. It has to do with what the college can offer to its clients in an environment that is favourable to all."

Student B: "Getting into unknown territory is frightening and full of uncertainties. Having SSS is of importance because it makes us come together as students from the different socio-economic background and cultural beliefs. That is how I understand it. Our needs are to be taken into consideration at the college."

Student C: "It has to do with assisting students with what they need during their entire schooling time at the college. This has to do with being given the total support by the administration, academic support, security, giving us guidance and for us to be able to approach the whole teaching staff for help. You see that is how I understand the Support Services."

Student D: "Yes, it has to do with every opportunity the college is to offer, that is, policy, and learning material, chance to access information, buildings and above all, lecturers to impart knowledge to students."

\section{Academic Opportunities Provided by Student Support Services}

Question 2: What academic opportunities are provided by the college?

When respondents were asked this question, seven themes emerged: academic needs, study groups, student assistants, non-discriminatory, wellness/healthy life, community of students, and study grants

Student A: "I think SSS is necessary for our academic needs and it can help in forming relationship amongst teachers and ourselves as new students. I think it helps us in establishing study groups in the classrooms."

Student D: "Yes! It helps us to be well informed about everything. Our needs are catered for, being academically, socially, spiritually and we are provided with teaching and learning materials such as computers in order to do assignments."

Student B: "I am telling you... student support services are the cornerstones of any institution. We have people who help us, students' representations and academic services which help in the enhancement of the skills of every individual without looking at who you are. This is done from the start of your enrollment until you leave the college. What a blessing!"

Student C: "The opportunities or benefits provided by student support services are amazing. Students are able to enjoy these anytime of their schooling time as long as they are prepared to abide by the rules of the college...student support services program should not be excluded from the daily activities of the college."

\section{Suggestions of Addressing Challenges Related to Student Support Services}

Question 3: What suggestions can you offer in addressing challenges you experience at the college?

When respondents were asked this question, seven themes dominated: supervisors, student-parent, breadwinners, encouragement, security, ownership, and benefits 
Student B: "Getting into unknown territory is frightening and full of uncertainties. Having SSS is of importance because it makes us come together as students from a different socio-economic background and cultural beliefs. Supervisors or guides should always be available to provide information."

Student C: "I am very confused with the dynamics of the college. If it was not for the SSS program I would be totally in the dark. At least it tells us what to expect, do, and how to get to places where we can access information. Newsletter, flyers and notices should be made available and be placed where students could easily access them."

Student D: "I am also lost. The college is too big, the curriculum is also confusing and we as students do not really know whom to ask for assistance with regard to the burden of being providers of our siblings at home. The SSS need to consider issues like this in order to make some impression on us. You know, some of us we are parents and breadwinners at home."

Student A: "The College should encourage students to participate vigorously in the program. They are to feel that it is for everybody who experiences academic, financial exclusion and other related issues. They need to own it so that they should feel at home until they leave the college."

\section{Discussion of Findings}

The results of this study, to a very great extent, at the TVET College, in particular, suggests that effective students support services as provided currently at the campus have an impact on their level of information regarding their studies. The majority of participants indicated through their responses that there is a probability that student support services contribute to the academic success. $77 \%$ of students agreed that for SSS to contribute to their academic success teaching and learning environment should be conducive for them to access without hurdles. This supported by Junio-Sabio (2012) when she alluded to the fact that providing academic amongst students in higher education is very important as evidenced by the overall of 3.4 obtained in the research conducted. Students (69\%) further agreed that student support services influence their academic success because of its programs. They further agreed (55\%) although just more than half of them, that the programs are helpful as they enable them to solicit information by having the opportunity of using top of the range technology.

All the participants (Participants A, B, C, and D) value the importance of students support services by indicating that the program is supportive as far as their needs were concerned, that is, providing them with support guidance when they want to register because policies and prospectors are made available. Junio-Sabio (2012) when she said, "enquiry assistance obtained the highest mean score of 3.75 which is verbally interpreted as important." They even feel that the anxiety that they have being experiencing when they want to join the college is minimised by the conducive atmosphere they encounter. Students also indicated that there are academic opportunities afforded them because they are able to access information from the libraries, student centres and thus becoming part of the college by surfing the internet for they own development.

\section{Conclusions}

All students need academic support and development, this does not mean that each student must get special attention over and above what lecturers are able to provide in the teaching and learning environment. A pre-emptive step to academic support would be to ensure that the regular teaching timetable for all subjects is planned in a way that facilitates teaching and learning in all components of the curriculum. A well-thought out campus timetable is the first foremost requirement for learning effectiveness. The colleges need to adopt a broader approach with regard to student support services and consider it as part of the curriculum. It should be systematically planned and should not be viewed as a program on its own. Students must be fully involved in the planning and implementation of student support services program. This will contribute to a greater extent to the awareness and, in general, to greater preparation on both the part of the lecturers and the students.

\section{REFERENCES}

[1] Department of Education. (2008). The different levels of comprehensive Student Support Services, Pretoria.

[2] Bailey, K. D. (1982). Methods of social research. London: The Free Press.

[3] Christensen, L. \& Johnson, B. (2012). Educational research: Quantitative, qualitative, and mixed approaches, ( $4^{\text {th }}$ edition $)$, Thousand Oaks, California: Sage.

[4] Clark, R. (2000). Appropriate research methods for electronic commerce. Retrieved November, 2015, from http://www.anu.edu.au/people/Roger.Clarke/EC/ResMeth.ht $\mathrm{ml}$

[5] Conrad, C.F. \& Serlin, R.C. (2011). The Sage handbook for research in education: Pursuing ideas as the keystone of exemplary inquiry, (2nd ed.). London: Sage.

[6] Creswell, J.W. (2005). Educational Research: Planning, conducting, and evaluating quantitative and qualitative research. Upper Saddle River, NJ: Merrill

[7] Creswell, J.W. (2014). Qualitative inquiry and Research Design: Choosing among five approaches (3ed.). California: SAGE Publications, inc.

[8] Gil-Jaurena, I. (2014).Student support services in open and distance education, Open Praxis, 6 (1), 3-4. DOI: http://dx.doi.org/10.5944/openpraxis.6.1.111 
[9] Crosling, G., Heagney, M., \& Thomas, L. (2009). Improving student retention in higher education: Improving teaching and learning. Australian Universities Review, 51(2), 1-10.

[10] Hichcock, G. \& Hughes, D. (1989). Research and the Teacher. Routledge.

[11] Fraenkel, J.R. \& Wallen, N.E. (1990). How to design and evaluate research in education, $\left(5^{\text {th }}\right.$ Ed.). Boston: McGraw-Hill.

[12] Junio-Sabio, C. (2012). Importance of academic support services: An assessment by the students in Oman. International Journal of Information Technology and Business Management, 3(1), 14-23)

[13] Leedy, P.D. \& Ormrod, J.E. (2010). Practical research: Planning and design, $\left(9^{\text {th }}\right.$ Ed). Upper Saddle river, New Jersey: Pearson.

[14] Mahlo, F.D. (2011). Experiences of Learning Support Teachers in the Foundation Phase, with Reference to the Implementation of Inclusive Education in Gauteng (Doctoral thesis).University Of South Africa, Pretoria

[15] Martins, J.H., Loubser, M. \& de J. Van Wyk, H. (1996). Marketing research: a South African approach, Pretoria: University of Pretoria.

[16] Motheo College Prospectus 2015: The gateway to employability, Department of Higher Education and Training,
Republic of South Africa, Bloemfontein, p1-40.

[17] Mulder, J.C. (1989). Statistical techniques in education, (Pretoria). Haum Educational Publisher,

[18] Mwamwenda, T.S. (2004). Educational Psychology; an African Perspective, $3^{\text {th }}$ ed., Heinemann, Sandton,

[19] Sax, G. (1979-80). Principles of Educational, Psychological measurement and evaluation, California: Wadsworth.

[20] Sibiya, K. (1989). My way... with Khulu Sibiya (re-privatization and Black attitudes), published on 4th June 1989. Railroad: Association of South Africa.

[21] Steyn, H.J. (1997). The structure of education systems, Noordbrug: Keurkopie.

[22] Steyn, H.J., Steyn, S.C., De Waal, E.A.S., \& Wolhuter, C.C. (2002). Die onderwysstelsel: struktuur en tendense. (The education system: structure and tendencies). Noordbrug: Keurkopie.

[23] Steyn, H.J. \& Wolhuter, C.C. (2008). The Education system and probable societal trends of the twenty-first century. In H.J. Steyn, \& C.C. Wolhuter (Eds.), Education Systems: Challenges of the 21st Century, Noordbrug: Keurkopie.

[24] Van Schalkwyk, O.J. (1996). Some theoretical thought on education systems, in E. Dekker \& O. J. Van Schalkwyk (Eds.), Modern Education Systems, Johannesburg: Heinemann. 